International Scientific Organization http://iscientific.org/

Chemistry International

www.bosaljournals.com/chemint/

\title{
Novel styryl and aza-styryl cyanine dyes: Synthesis and spectral sensitization evaluation
}

\author{
Hassan Abazied Shindy*, Mohamed Abdallah El-Maghraby, Maha Mubark Goma and Nemat \\ Abdelrahman Harb
}

Department of Chemistry, Faculty of Science, Aswan University, Aswan 81528, Egypt

*Corresponding author's E. mail: hashindy2@hotmail.com

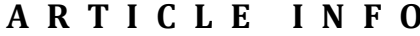

Article type:

Research article

Article history:

Received July 2018

Accepted October 2018

April 2019 Issue

Keywords:

Cyanine dyes

Styryl cyanine dyes

Synthesis

Absorption spectra

Aza-styryl cyanine dyes

Spectral sensitization evaluation
A B S T R A C T

Novel styryl cyanine dyes and aza-styryl cyanine dyes having the nucleus of furo[(3,2-d)pyrazole; $\left(3^{\prime}, 2^{\prime}-\right.$ d)oxazole] iodide salt were prepared. Spectral sensitization evaluation for all the synthesized styryl and aza-styryl cyanine dyes was carried out through investigating their electronic visible absorption spectra in 95\% ethanol solution. The dyes were thought to be better spectral sensitizers when they absorb light at longer wavelength bands (bathochromic shifted and/or red shifted dyes). Consequently the spectral sensitization of the dyes decreased when they absorb light at shorter wavelength bands (hypsochromic shifted and/or blue shifted dyes). The results discussed in this study revealed that the spectral sensitization properties of the examined dyes is highly effected by the type of the $\mathrm{X}$ substituted in the phenyl ring system for the styryl cyanine dyes and by the type of the phenyl and/or the naphthyl ring system for the aza-styryl cyanine dyes. Structural confirmations were identified by elemental analysis, visible spectra, IR and ${ }^{1} \mathrm{H}$ NMR spectroscopic data.

(c) 2019 International Scientific Organization: All rights reserved.

Capsule Summary: Novel styryl and aza-styryl cyanine dyes were synthesized and the spectral sensitization of as-synthesized dyes has been evaluated.

Cite This Article As: H. A. Shindy, M. A. El-Maghraby, M. M. Goma and N. A. Harb. Novel styryl and aza-styryl cyanine dyes: Synthesis and spectral sensitization evaluation. Chemistry International 5(2) (2019) 117-125.

\section{INTRODUCTION}

Sytryl cyanine dyes (Shindy, 2012; Shindy, 2015; Shindy, 2014) can be used as fluorescence probes in biochemistry and biophysical area (Ephardt and Fromherz, 1989). They are also commonly applied to lasers, electronics and nonlinear optics (Zhao, et al., 1996; Gromov, et al., 1992; He, et al., 1995). Styryl cyanine dyes are a type of important functional cyanine dye, which has been widely applied in many areas, such as frequency-upconverted lasing, optical power limiting, molecular electronics and as novel and successful fluorescent probes in numerous bioanalytical methods, especially in RNR and DNA analysis (Shindy, 2016; Jedrzejewska, et al., 2003; Hong, et al., 2004; Kovalska, et al., 2005).

In addition, styryl cyanine dyes are also widely used as sensitisers and other additives in the photographic industry (Mees and James, 1979; Hamer, 1964; Pierre, 1984), and these dyes represent an important group of biologically active compounds and are widely applied in the pharmaceutical industry (Preston, 1980).

Besides, styryl cyanine dyes (Antonious, 1997; Kabatc, et al., 2006; Huang and Coull, 2008; Shindy, 2007; 
Shim, et al., 2009; Jedrzejewska, et al., 2010; Deligeorgiev, et al., 2010; Vasilev, et al., 2008; Shindy , 2015a; Li, et al., 1998; Matsuoka and Fukunishi, 1996) have a number of good properties, such as ease synthesis, they fluorescent, have higher photostability than the classical cyanine dyes and they can cover the spectrum from the UV to near infrared (NIR) region.

In this research, a novel series of styryl and azastyryl cyanine dyes as new synthesis contribution were prepared and spectroscopic investigation in the field, and to may be used and/or applied in any of the broad area uses and applications of cyanine dyes, and particularly as photographic sensitizers in photosensitive material industry, as indicators in acid-base titration in analytical chemistry, as probes for determining solvent polarity in solution chemistry and as anti-bacterial strains and anti-fungi strains in pharmaceutical (pharmacological) industry and/or in pharmacochemistry.

\section{MATERIAL AND METHODS}

\section{General}

All the melting points of the prepared compounds are measured using Electrothermal 15V, 45W 1 A9100 melting point apparatus (Chemistry Department, Faculty of Science, Aswan University, Aswan, Egypt) and are uncorrected. Elemental analysis was carried out at the Microanalytical Center of Cairo University by an automatic analyzer (Vario EL III Germany). Infrared spectra were measured with a FT-IR (4100 Jasco, Japan), Cairo University. ${ }^{1}$ HNMR spectra were accomplished using Varian Gemini-300 MHz NMR Spectrometer (Cairo University). Electronic visible absorption spectra were carried out on vis spectrophotometer spectra 24 RS Labomed, INC. (Chemistry Department, Faculty of Science, Aswan University, Aswan, Egypt).

\section{Synthesis}

Synthesis of 4,6-diethyl-5-methyl-7-phenyl-furo[(3,2-d) pyrazolium;(3', 2'-d)oxazolium-3(1)-styryl cyanine dyes (2af): 1:1 molar ratios of the quaternized compound (1) (0.01 mol, $0.57 \mathrm{gm})$ and the aromatic aldehyde $(0.01 \mathrm{~mol})$ [benzaldehyde $(0.1 \mathrm{gm}), 4$-hydroxy benzaldehyde $(0.12 \mathrm{gm})$, 4-methoxy benzaldehyde $(0.12$ gm), p.Ndimethylaminobenzaldehyde ( $0.15 \mathrm{gm})$, 4-nitrobenzaldehyde $(0.15 \mathrm{gm})$ or 4 -chlorobenzaldehyde $(0.14 \mathrm{gm})]$ were heated under reflux in ethanol $(50 \mathrm{ml})$ as solvent containing piperidine $(1 \mathrm{ml})$ as a catalyst for $6 \mathrm{hrs}$. The reaction mixture changed from reddish colours to dark brown colours at the end of refluxing. It was filtered while hot to remove any impurities, cooled, and precipitated by ice-water mixture. The styryl cyanine dyes (2a-f) were collected, washed with water several times, dried and crystallized from ethanol, Table (1).
Sythesis of 4,6-diethyl-7-phenyl-furo[(3,2-d) pyrazolium; (3',2'-d)oxazolium-3,5(1)-bis styryl cyanine dyes (3a-f): Two different routes are employed to prepare this series of cyanine dyes:

Route (1): unimolar ratios of the quaternized compound (1) (0.01 mol, $0.57 \mathrm{gm})$ and bimolar ratios of either the aromatic aldehyde $(0.02 \mathrm{~mol})$ [benzaldehyde $(0.2$ gm), 4-hydroxy benzaldehyde (0.24 gm), 4-methoxy benzaldehyde $(0.24 \mathrm{gm})$, p.N-dimethylaminobenzaldehyde (0.3 gm), 4-nitrobenzaldehyde $(0.3 \mathrm{gm})$ or 4chlorobenzaldehyde $(0.28 \mathrm{gm})$ were heated under reflux in ethanol $(50 \mathrm{ml})$ as solvent containing piperidine $(1 \mathrm{ml})$ as a catalyst for 6 hrs. The reaction mixture changed from reddish color to dark brown at the end of refluxing. It was filtered while hot, cooled, neutralized by glacial acetic acid and precipitated by ice-water mixture. The bis styryl cyanine dyes were collected, washed with water, air dried and crystallized from ethanol, see Table (2).

Route (2): was carried out through dissolving the previously prepared 3(1)-styryl cyanine dyes (2a-f) $(0.01$ mol) ( $0.65 \mathrm{gm}$ for $2 \mathrm{a}, 0.67 \mathrm{gm}$ for $2 \mathrm{~b}, 0.68 \mathrm{gm}$ for $2 \mathrm{c}, 0.7 \mathrm{gm}$ for $2 \mathrm{~d}, 0.7 \mathrm{gm}$ for $2 \mathrm{e}, 0.69 \mathrm{gm}$ for $2 \mathrm{f}$ ) and equimolar ratios of either the aromatic aldehyde $(0.01 \mathrm{~mol})$ [benzaldehyde $(0.1$ gm), 4-hydroxy benzaldehyde (0.12 gm), 4-methoxy benzaldehyde (0.12 gm), p.N-dimethylaminobenzaldehyde (0.15 gm), 4-nitrobenzaldehyde $(0.15 \mathrm{gm})$ or 4chlorobenzaldehyde $(0.14 \mathrm{gm})]$ in ethanol $(50 \mathrm{ml})$, containing piperidine $(1 \mathrm{ml})$. The reacting materials were heated under reflux for 6 hours, and attained a permanent intense brown colour at the end of the reflux. It was filtered off while hot, concentrated, cooled, neutralized by acetic acid and precipitated by adding cold water. The precipitates were collected and recrystallized from ethanol to give the same 3,5(1)-bis styryl cyanine dyes obtained by route (1) characterized by melting points, mixed melting points, same visible IR and ${ }^{1} \mathrm{H}-\mathrm{NMR}$ spectral data.

Synthesis of 4,6-diethyl-5-methyl-7-phenylfuro[(3,2-d) pyrazolium;(3', 2'-d)oxazolium-3[2(1)]-aza-styryl cyanine dyes (4a-c): An equimolar ratios of the quaternized compound (1) (0.01 mol, $0.57 \mathrm{gm})$ and nitroso compouds ( $0.01 \mathrm{~mol})$ of either 4-nitroso phenol (0.12 gm), 1-nitroso-2naphthol (0.17 gm) or 2-nitroso-1-naphthol $(0.17 \mathrm{gm})$ in ethanol $(50 \mathrm{ml})$ containing piperidine $(1 \mathrm{ml})$ were heated under reflux for $6 \mathrm{hrs}$. The reaction mixture which attained a deep permanent colour at the end of the refluxing time was filtered on hot to remove any impurities, precipitated using ice-water mixture, filtered and air dried. The aza-styryl cyanine dyes (4a-c) were collected and crystallized using ethanol. See the data given in Table (3).

Synthesis of 4,6-diethyl-7-phenyl-furo[(3,2-d) pyrazolium; $(3 ', 2$ '-d)oxazolium-3,5[2(1)]-bis aza-styryl cyanine dyes (5ac): This synthesis was proceeded through two different routes as following:

Route (1): Amixture of unimolar ratios of the quaternized compound (1) (0.01 mol, $0.57 \mathrm{gm})$ and bimolar ratios of the nitroso compounds $(0.02 \mathrm{~mol})$ of either [4- 


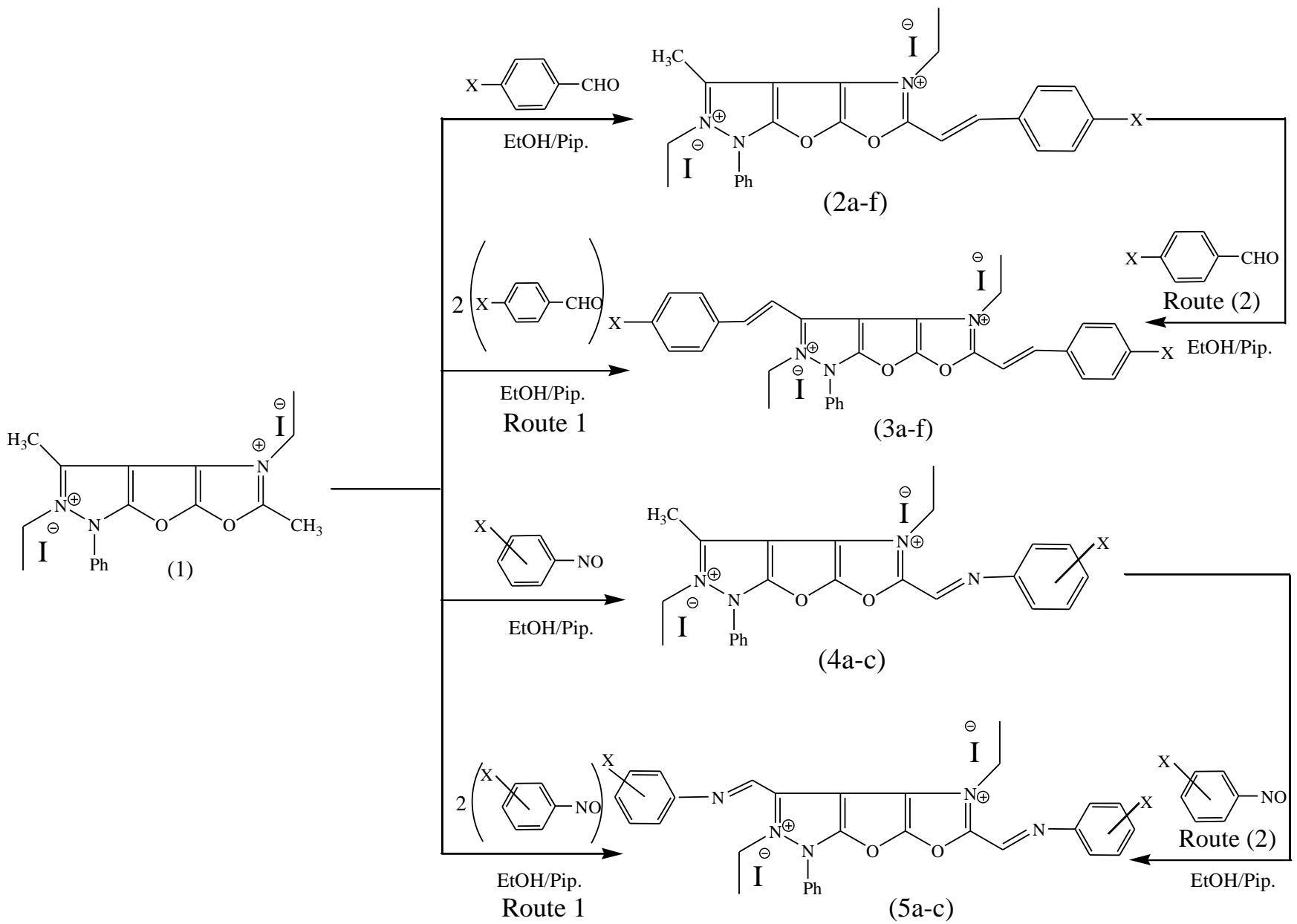

Scheme 1: Synthesis Strategy of the prepared compounds (2a-f), (3a-f), (4a-c), and (5a-c)

[(2a-f), (3a-f): $\mathrm{X}=\mathrm{H}$ (a), $\mathrm{OH}(\mathrm{b}), \mathrm{OCH}_{3}(\mathrm{c}),\left(\mathrm{CH}_{3}\right)_{2} \mathrm{~N}$ (d), $\mathrm{NO}_{2}$ (e), $\mathrm{Cl}(\mathrm{f}),(4 a-c),(5 a-c): \mathrm{X}=4 . \mathrm{OH}(\mathrm{a}), 2 . \mathrm{OH}, 3$, 4-benzo (b), 2.OH, 5, 6-benzo (c)].

nitroso phenol (0.24 gm), 2-nitroso-1-naphthol (0.34 gm), or 1-nitroso-2-naphthol $(0.34 \mathrm{gm})]$ in ethanol $(50 \mathrm{ml})$ containing basic catalyst piperidine $(1 \mathrm{ml})$ were heated under reflux for 6 hrs. The reaction mixture was filtered on hot to remove impurities, precipitated using crushed ice, neutralized with glacial acetic acid, collected and crystallized using ethanol. See Table (3).

Route (2): Was carried out through dissolving the previously prepared aza-styryl cyanine dyes $(4 \mathrm{a}-\mathrm{c})(0.01 \mathrm{~mol}$, $0.67 \mathrm{gm}$ for $4 \mathrm{a}, 0.72 \mathrm{gm}$ for $4 \mathrm{~b}, 0.72 \mathrm{gm}$ for $4 \mathrm{c}$ ) and equimolar ratios of the nitroso compounds $(0.01 \mathrm{~mol})$ of either [4nitroso phenol (0.24 gm), 2-nitroso-1-naphthol (0.34 gm), or 1-nitroso-2-naphthol $(0.34 \mathrm{gm})]$ in ethanol $(50 \mathrm{ml})$ containing piperidine $(1 \mathrm{ml})$. The reacting materials were heated under reflux for $6 \mathrm{hrs}$ and attained a permanent intense brown colour at the end of the reflux. It was filtered off while hot, concentrated, cooled, neutralized by acetic acid and precipitated by adding cold water. The precipitates were collected and recrystallized from ethanol to give the same bis aza-styryl cyanine dyes (5a-c) obtained by route (1), Table
(3), characterized by melting points, mixed melting points, same visible, IR and ${ }^{1} \mathrm{H}-\mathrm{NMR}$ spectral data.

\section{Spectral studies}

The electronic visible absorption spectra of the prepared cyanine dyes were examined in 95\% ethanol solution and recorded using $1 \mathrm{Cm} \mathrm{Qz}$ cell in visible spectrophotometer, spectro 24 RS Labomed, INC. A stock solution $\left(1 \times 10^{-3} \mathrm{M}\right)$ of the dyes was prepared and diluted to a suitable volume in order to obtain the desired lower concentrations. The spectra were recorded immediately to eliminate as much as possible the effect of time.

\section{RESULTS AND DISCUSSION}

\section{Synthesis}

Reaction of the compound 4,6-diethyl-3,5-dimethyl-7phenyl-furo[(3,2-d) pyrazolium;(3',2'-d)oxazolium] 


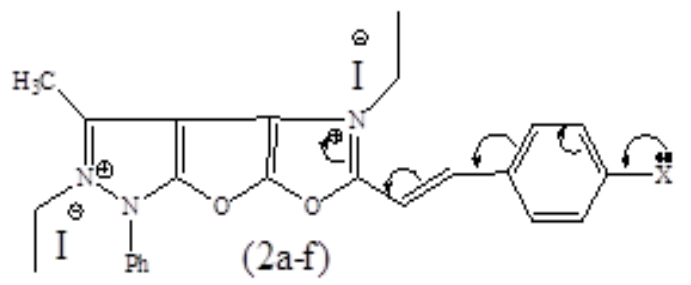

(A)

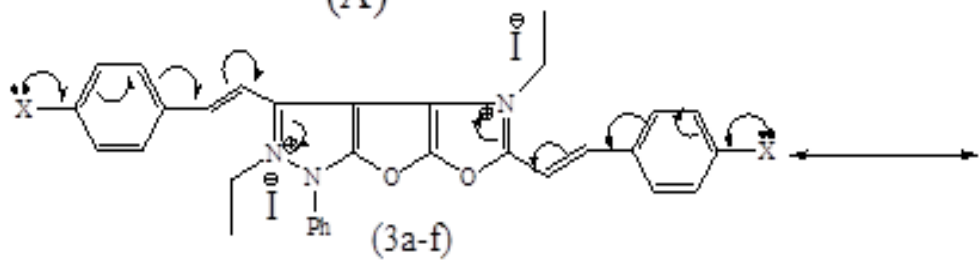

(A)

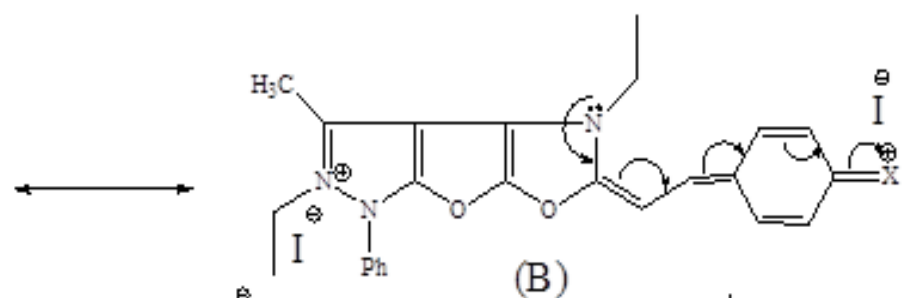

(B)

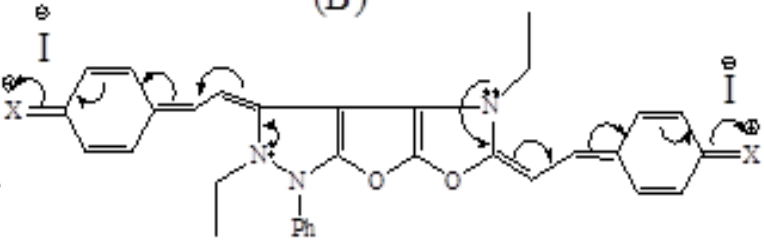

(B)

Scheme 2a: Colour intensity and the electronic charge transfer pathways illustration of the synthesized styryl cyanine (bis styryl cyanine) dyes 2a-f (3a-f).

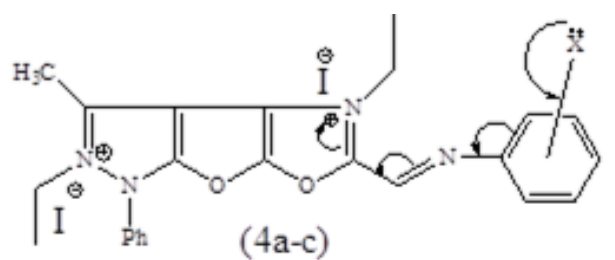

(A)

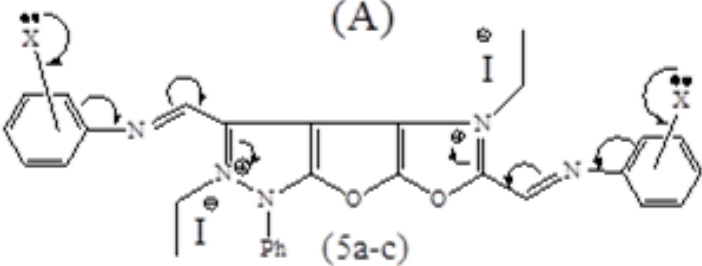

(A)

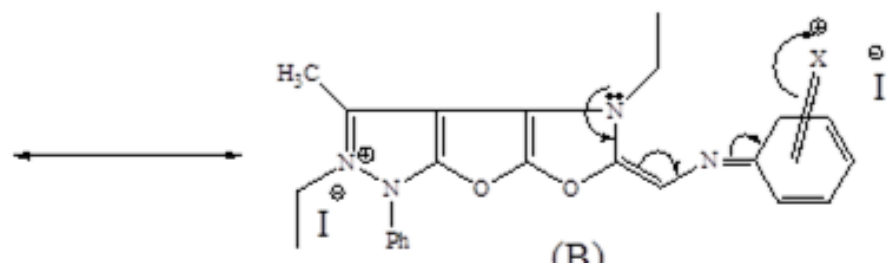

(B)

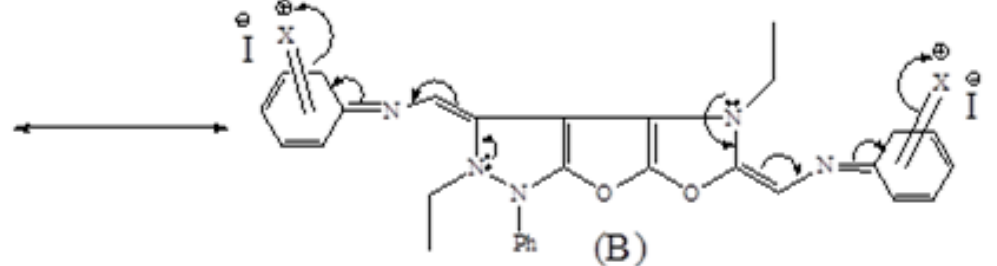

(B)

Scheme 2b: Colour intensity and the electronic charge transfer pathways illustration of the synthesized aza-styryl cyanine (bis aza-styryl cyanine) dyes 2a-f (3a-f).

diiodide quaternary salt (1) and an equimolar or bimolar ratios of the given aromatic aldehydes, (benzaldehyde, p.OH benzaldehyde, p.OCH 3 benzaldehyde, p.N $\left(\mathrm{CH}_{3}\right)_{2}$ benzaldehyde, $\mathrm{p} . \mathrm{NO}_{2}$ benzaldehyde, $\mathrm{p} . \mathrm{Cl}$ benzaldehyde) in ethanol containing piperidine as a basic catalyst afforded the 3(1)-styryl cyanines (2a-f) or 3,5(1)-bis styryl cyanines (3a-f) (Scheme 1, Route 1).

Chemical confirmations for the 3,5(1)-bis styryl cyanine dyes (3a-f) were also carried out through Route (2), Scheme (1) via reactions of the previously prepared 3(1)-styryl cyanine dyes (2a-f) with an equimolar ratios of the aromatic aldehydes (benzaldehyde, 4-hydroxy benzaldehyde, 4-methoxy benzaldehyde, p.Ndimethylaminobenzaldehyde, 4-nitrobenzaldehyde and 4chlorobenzaldehyde) in ethanol containing piperidine to achieve the same 3,5(1)-bis styryle cyanine dyes (3a-f) obtained through Route (1), characterized by the same melting points, mixed melting points, the same visible, IR and ${ }^{1} \mathrm{H}-\mathrm{NMR}$ spectra (Scheme 1, Route 2).
The reaction of the diquaternized compound (1) with equimolar and/or bimolar ratios of nitroso compounds (4-nitroso phenol, 2-nitroso-1-naphthol, or 1nitroso-2-naphthol) in ethanol containing basic catalyst piperidine yielded the aza-styryl cyanine dyes (4a-c) and/or the bis aza-styryl cyanine dyes $(5 a-c)$, respectively (Scheme 1, Route 1).

Chemical confirmations were carried out through the reactions of the previously prepared aza-styryl cyanine dyes (4a-c) with equimolar ratios of the nitroso compounds (4-nitroso phenol, 1-nitroso-2-naphthol, 2-nitroso-1naphthol) in ethanol catalyzed by piperidine through Route (2), to achieve the same bis aza-styryl cyanine dyes (5a-c) obtained by Route (1), characterized by the same melting points, mixed melting points, the same visible, IR and ${ }^{1} \mathrm{H}-$ NMR spectra (Scheme 1, Route 2).

The structure of the prepared compound was characterized and identified by elemental analysis, Tables (1), (2) and (3), 
Table 1: Characterization of the prepared compounds (2a-f)

\begin{tabular}{|c|c|c|c|c|c|c|c|c|c|c|c|c|}
\hline \multirow[t]{3}{*}{ Coms } & \multirow[t]{3}{*}{ Colour } & \multirow{3}{*}{$\begin{array}{c}\text { Yield } \\
\% \\
\end{array}$} & \multirow{3}{*}{$\begin{array}{c}\text { M. P } \\
{ }^{\circ} \mathrm{C} \\
\end{array}$} & \multirow[t]{3}{*}{ MF (MW) } & \multicolumn{6}{|c|}{ Composition analysis (\%) } & \multicolumn{2}{|c|}{ Abs. (in 95\% ethanol) } \\
\hline & & & & & \multicolumn{3}{|c|}{ Calculated } & \multicolumn{3}{|c|}{ Found } & \multirow{2}{*}{$\begin{array}{l}\lambda_{\max } \\
\mathrm{nm}\end{array}$} & \multirow{2}{*}{$\begin{array}{c}\varepsilon_{\max } \\
\operatorname{mol}^{-1} \cdot \mathrm{cm}^{2}\end{array}$} \\
\hline & & & & & $\mathrm{C}$ & $\mathrm{H}$ & $\mathrm{N}$ & $\mathrm{C}$ & $\mathrm{H}$ & $\mathrm{N}$ & & \\
\hline $2 \mathrm{a}$ & $\begin{array}{l}\text { Deep } \\
\text { brown }\end{array}$ & 42 & 140 & $\begin{array}{c}\mathrm{C}_{25} \mathrm{H}_{25} \mathrm{~N}_{3} \mathrm{O}_{2} \mathrm{I}_{2} \\
(653)\end{array}$ & 45.94 & 8.83 & 6.43 & 45.92 & 8.79 & 6.41 & $\begin{array}{c}440,460 \\
600\end{array}$ & $\begin{array}{c}13240 \\
13370,6800\end{array}$ \\
\hline $2 b$ & $\begin{array}{l}\text { Deep } \\
\text { brown }\end{array}$ & 53 & 125 & $\begin{array}{c}\mathrm{C}_{25} \mathrm{H}_{25} \mathrm{~N}_{3} \mathrm{O}_{3} \mathrm{I}_{2} \\
(669)\end{array}$ & 44.84 & 3.74 & 6.28 & 44.81 & 3.69 & 6.22 & $\begin{array}{c}450,470 \\
610\end{array}$ & $\begin{array}{c}12050 \\
11680,6600\end{array}$ \\
\hline $2 \mathrm{c}$ & $\begin{array}{l}\text { Deep } \\
\text { brown }\end{array}$ & 43 & 150 & $\begin{array}{c}\mathrm{C}_{26} \mathrm{H}_{27} \mathrm{~N}_{3} \mathrm{O}_{3} \mathrm{I}_{2} \\
(683)\end{array}$ & 45.68 & 3.95 & 6.15 & 45.63 & 3.93 & 6.12 & $\begin{array}{c}480,520 \\
620\end{array}$ & $\begin{array}{c}11370 \\
10150,6120\end{array}$ \\
\hline $2 d$ & $\begin{array}{l}\text { Deep } \\
\text { brown }\end{array}$ & 45 & 115 & $\begin{array}{c}\mathrm{C}_{27} \mathrm{H}_{30} \mathrm{~N}_{4} \mathrm{O}_{2} \mathrm{I}_{2} \\
(696)\end{array}$ & 46.55 & 4.31 & 8.05 & 46.51 & 4.28 & 8.01 & $\begin{array}{l}480,500 \\
530,630\end{array}$ & $\begin{array}{c}12600 \\
14110 \\
12400,6150\end{array}$ \\
\hline $2 \mathrm{e}$ & $\begin{array}{l}\text { Deep } \\
\text { brown }\end{array}$ & 48 & 145 & $\begin{array}{c}\mathrm{C}_{25} \mathrm{H}_{24} \mathrm{~N}_{4} \mathrm{O}_{4} \mathrm{I}_{2} \\
(698)\end{array}$ & 42.98 & 3.44 & 8.02 & 42.95 & 3.41 & 8.01 & $\begin{array}{l}430,450 \\
490,590\end{array}$ & $\begin{array}{l}9690,11020, \\
10530,4990\end{array}$ \\
\hline $2 f$ & $\begin{array}{l}\text { Deep } \\
\text { brown }\end{array}$ & 50 & 130 & $\begin{array}{c}\mathrm{C}_{25} \mathrm{H}_{24} \mathrm{~N}_{3} \mathrm{O}_{2} \mathrm{I}_{2} \\
\mathrm{Cl}(687.6)\end{array}$ & 43.63 & 3.49 & 6.11 & 43.59 & 3.44 & 6.8 & $\begin{array}{c}420,450 \\
580\end{array}$ & $\begin{array}{c}13770 \\
13850,7410\end{array}$ \\
\hline
\end{tabular}

Coms = Compounds, MF = Molecular formula, MW = Molecular weight and Abs = absorbance

Table 2: Characterization of the prepared compounds (3a-f)

\begin{tabular}{|c|c|c|c|c|c|c|c|c|c|c|c|c|}
\hline \multirow[t]{3}{*}{ Coms } & \multirow[t]{3}{*}{ Colour } & \multirow{3}{*}{$\begin{array}{c}\text { Yield } \\
\% \\
\end{array}$} & \multirow{3}{*}{$\begin{array}{c}\text { M. P } \\
{ }^{\circ} \mathrm{C} \\
\end{array}$} & \multirow[t]{3}{*}{$\mathrm{MF}(\mathrm{MW})$} & \multicolumn{6}{|c|}{ Composition analysis (\%) } & \multicolumn{2}{|c|}{ Abs. (in 95\% ethanol) } \\
\hline & & & & & \multicolumn{3}{|c|}{ Calculated } & \multicolumn{3}{|c|}{ Found } & \multirow{2}{*}{$\begin{array}{l}\lambda_{\max } \\
\mathrm{nm}\end{array}$} & \multirow{2}{*}{$\begin{array}{c}\varepsilon_{\max } \\
\mathrm{mol}^{-1} \cdot \mathrm{cm}^{2}\end{array}$} \\
\hline & & & & & $\mathrm{C}$ & $\mathrm{H}$ & $\mathrm{N}$ & $\mathrm{C}$ & $\mathrm{H}$ & $\mathrm{N}$ & & \\
\hline $3 a$ & $\begin{array}{l}\text { Deep } \\
\text { brown }\end{array}$ & 49 & 145 & $\begin{array}{c}\mathrm{C}_{32} \mathrm{H}_{29} \mathrm{~N}_{3} \mathrm{O}_{2} \mathrm{I}_{2} \\
(741)\end{array}$ & 51.82 & 3.91 & 5.67 & 51.8 & 3.89 & 5.64 & $\begin{array}{c}460 \\
480,610\end{array}$ & $\begin{array}{c}12570 \\
14100,7490\end{array}$ \\
\hline $3 b$ & $\begin{array}{l}\text { Deep } \\
\text { brown }\end{array}$ & 52 & 135 & $\begin{array}{c}\mathrm{C}_{32} \mathrm{H}_{29} \mathrm{~N}_{3} \mathrm{O}_{4} \mathrm{I}_{2} \\
(773)\end{array}$ & 49.68 & 3.75 & 5.43 & 49.65 & 3.71 & 5.41 & $\begin{array}{c}460 \\
490,620\end{array}$ & $\begin{array}{c}11760 \\
13570,6370\end{array}$ \\
\hline $3 c$ & $\begin{array}{l}\text { Deep } \\
\text { brown }\end{array}$ & 57 & 160 & $\begin{array}{c}\mathrm{C}_{34} \mathrm{H}_{33} \mathrm{~N}_{3} \mathrm{O}_{4} \mathrm{I}_{2} \\
(801)\end{array}$ & 50.94 & 4.12 & 5.24 & 50.91 & 4.09 & 5.21 & $\begin{array}{c}470 \\
500,630\end{array}$ & $\begin{array}{c}12280 \\
13110,6320\end{array}$ \\
\hline $3 d$ & $\begin{array}{l}\text { Deep } \\
\text { brown }\end{array}$ & 46 & 120 & $\begin{array}{c}\mathrm{C}_{36} \mathrm{H}_{39} \mathrm{~N}_{5} \mathrm{O}_{2} \mathrm{I}_{2} \\
(827)\end{array}$ & 52.24 & 4.72 & 8.46 & 52.22 & 4.68 & 8.41 & $\begin{array}{c}480, \\
500, \\
540,640\end{array}$ & $\begin{array}{c}13160 \\
15210 \\
12870,6330\end{array}$ \\
\hline $3 e$ & $\begin{array}{l}\text { Deep } \\
\text { brown }\end{array}$ & 49 & 150 & $\begin{array}{c}\mathrm{C}_{32} \mathrm{H}_{27} \mathrm{~N}_{5} \mathrm{O}_{6} \mathrm{I}_{2} \\
(831)\end{array}$ & 46.21 & 3.25 & 8.42 & 46.17 & 3.22 & 8.4 & $\begin{array}{c}450 \\
470 \\
500,600\end{array}$ & $\begin{array}{c}8520,10640 \\
8000,4490\end{array}$ \\
\hline $3 f$ & $\begin{array}{l}\text { Deep } \\
\text { brown }\end{array}$ & 54 & 135 & $\begin{array}{c}\mathrm{C}_{32} \mathrm{H}_{27} \mathrm{~N}_{3} \mathrm{O}_{2} \mathrm{I}_{2} \mathrm{Cl}_{2} \\
(810)\end{array}$ & 47.41 & 3.33 & 5.19 & 47.39 & 3.28 & 5.15 & $\begin{array}{c}440 \\
460,590\end{array}$ & $\begin{array}{c}10670 \\
11760,6870\end{array}$ \\
\hline
\end{tabular}

Explanations as in Table 1

visible spectra, Tables (1), (2) and (3), IR (Wade, 1999) and ${ }^{1} \mathrm{H}$-NMR (Wade, 1999a) spectroscopic data, Table (4).

\section{Spectral sensitization evaluation}

Spectral sensitization evaluation for all the synthesized cyanine dyes was carried out through investigating their electronic visible absorption spectra in $95 \%$ ethanol solution. The dyes were thought to be better spectral sensitizers when they absorb light at longer wavelength bands (bathochromic shifted and/or red shifted dyes).
Consequently the spectral sensitization of the dyes decrease when they absorb light at shorter wavelength bands (hypsochromic shifted and/or blue shifted dyes). So, we may say that the spectral sensitization of one dye is higher than the other one if the wavelength of the maximum absorption spectrum of the former one is longer than that of the latter one. Inversely, we may say that the spectral sensitization of one dye is lower than the other one if the wavelength of the maximum absorption spectrum of the former one is shorter than that of the latter one (Shindy, et al., 2017; Shindy, 2017). 
Table 3: Characterization of the prepared compounds (4a-c) and (5a-c)

\begin{tabular}{|c|c|c|c|c|c|c|c|c|c|c|c|c|}
\hline \multirow[t]{3}{*}{ Coms } & \multirow[t]{3}{*}{ Colour } & \multirow{3}{*}{$\begin{array}{c}\text { Yield } \\
\% \\
\end{array}$} & \multirow{3}{*}{$\begin{array}{l}\text { M. P } \\
{ }^{\circ} \mathrm{C} \\
\end{array}$} & MF (MW) & \multicolumn{6}{|c|}{ Composition analysis (\%) } & \multicolumn{2}{|c|}{ Abs. (in 95\% ethanol) } \\
\hline & & & & & \multicolumn{3}{|c|}{ Calculated } & \multicolumn{3}{|c|}{ Found } & \multirow{2}{*}{$\begin{array}{l}\lambda_{\max } \\
\mathrm{nm}\end{array}$} & \multirow{2}{*}{$\begin{array}{c}\varepsilon_{\max } \\
\operatorname{mol}^{-1} \cdot \mathrm{cm}^{2}\end{array}$} \\
\hline & & & & & $\mathrm{C}$ & $\mathrm{H}$ & $\mathrm{N}$ & $\mathrm{C}$ & $\mathrm{H}$ & $\mathrm{N}$ & & \\
\hline $4 a$ & $\begin{array}{l}\text { Deep } \\
\text { brown }\end{array}$ & 55 & 120 & $\begin{array}{c}\mathrm{C}_{24} \mathrm{H}_{24} \mathrm{~N}_{4} \mathrm{O}_{3} \mathrm{I}_{2} \\
(670)\end{array}$ & 42.99 & 3.58 & 8.36 & 42.95 & 3.54 & 8.33 & 440,580 & 14220,7030 \\
\hline $4 b$ & $\begin{array}{l}\text { Deep } \\
\text { brown }\end{array}$ & 58 & 135 & $\begin{array}{c}\mathrm{C}_{28} \mathrm{H}_{26} \mathrm{~N}_{4} \mathrm{O}_{3} \mathrm{I}_{2} \\
(720)\end{array}$ & 46.67 & 3.61 & 7.78 & 46.64 & 3.59 & 7.74 & 460,590 & 12680,9940 \\
\hline $4 c$ & $\begin{array}{l}\text { Deep } \\
\text { brown }\end{array}$ & 56 & 160 & $\begin{array}{c}\mathrm{C}_{28} \mathrm{H}_{26} \mathrm{~N}_{4} \mathrm{O}_{3} \mathrm{I}_{2} \\
(720)\end{array}$ & 46.67 & 3.61 & 7.78 & 46.62 & 3.57 & 7.73 & 470,600 & 12210,8370 \\
\hline $5 a$ & $\begin{array}{l}\text { Deep } \\
\text { brown }\end{array}$ & 59 & 130 & $\begin{array}{c}\mathrm{C}_{30} \mathrm{H}_{27} \mathrm{~N}_{5} \mathrm{O}_{4} \mathrm{I}_{2} \\
(775)\end{array}$ & 46.45 & 3.48 & 9.03 & 46.43 & 3.45 & 9.01 & 450,590 & 15480,7970 \\
\hline $5 b$ & $\begin{array}{l}\text { Deep } \\
\text { brown }\end{array}$ & 60 & 145 & $\begin{array}{c}\mathrm{C}_{38} \mathrm{H}_{31} \mathrm{~N}_{5} \mathrm{O}_{4} \mathrm{I}_{2} \\
(875)\end{array}$ & 52.11 & 3.54 & 8 & 52.09 & 3.51 & 7.97 & 460,600 & 11990,8440 \\
\hline $5 c$ & $\begin{array}{l}\text { Deep } \\
\text { brown }\end{array}$ & 62 & 170 & $\begin{array}{c}\mathrm{C}_{38} \mathrm{H}_{31} \mathrm{~N}_{5} \mathrm{O}_{4} \mathrm{I}_{2} \\
(875)\end{array}$ & 52.11 & 3.54 & 8 & 52.08 & 3.52 & 7.98 & $\begin{array}{c}480,510 \\
610\end{array}$ & $\begin{array}{c}12780 \\
11700,7380\end{array}$ \\
\hline
\end{tabular}

Explanations as in Table 1

Spectral sensitization evaluation study is very important in the case of cyanine dyes because the extensive uses of these dyes in photographic material industry to increase the sensitivity range of silver halide emulsion by making an increase in the range of wavelength which form an image on the film.

The visible electronic absorption spectra of the styryl cyanine dyes (bis styryl cyanine dyes) 2a-f (3a-f) in 95\% ethanol solution gives bands in visible region 440-630 $\mathrm{nm}$ (460-640 nm). These bands underwent displacements to give bathochromic shifts (red shifts) and or hypsochromic shifts (blue shifts) in addition to increasing and or decreasing the intensity of the absorption bands depending upon the type of the $\mathrm{X}$ substituents in the phenyl ring system, Tables (1) and (2).

So, substituting $\mathrm{X}=\mathrm{H}$ in dyes $2 \mathrm{a}(3 \mathrm{a})$ by $\mathrm{X}=\mathrm{OH}$, $\mathrm{OCH}_{3}$ and or $\mathrm{N}\left(\mathrm{CH}_{3}\right)_{2}$ to obtain dyes $2 \mathrm{~b}(3 \mathrm{~b}), 2 \mathrm{c}(3 \mathrm{c})$ and or 2d (3d) makes bathochromic shifts for the absorption bands by $10 \mathrm{~nm}, 20 \mathrm{~nm}, 30 \mathrm{~nm}$, in addition to increasing for the intensity of the bands, respectively, Tables (1) and (2). This can be attributed to the electron pushing characters of the $\mathrm{OH}, \mathrm{OCH}_{3}$ and or $\mathrm{N}\left(\mathrm{CH}_{3}\right)_{2}$ groups in the latter dyes, which increase and or facilitate the intensity of the electronic charge transfer to the quaternary nitrogen atom of the pyrazolium and or oxazolium iodide salt (acidic center of the dyes) and consequently red shifts occurs for the bands of these latter dyes $2 b(3 b), 2 c(3 c), 2 d(3 d)$ in correspondence to the former parent dyes $2 \mathrm{a}(3 \mathrm{a})$.

Substituting $\mathrm{X}=\mathrm{H}$ by $\mathrm{X}=\mathrm{NO}_{2}$ and or $\mathrm{Cl}$ moving from dyes $2 \mathrm{a}(3 \mathrm{a})$ to $2 \mathrm{e}(3 \mathrm{e}$ ) and or $2 \mathrm{f}$ (3f) causes blue shifts for the absorption bands by $10 \mathrm{~nm}$ and or $20 \mathrm{~nm}$, accompanied by quenching the intensity of these bands, respectively, Tables (1) and (2). This can be related to the strong electron pulling characters of the $\mathrm{NO}_{2}$ group and or the $\mathrm{Cl}$ atom in the latter dyes $2 \mathrm{e}(3 \mathrm{e})$ and or $2 \mathrm{f}(3 \mathrm{f})$ which make decreasing for intensity of electronic charge transfer to the quaternary nitrogen of pyrazolium and or oxazolium salt residue (acidic center of the dyes), and accordingly hypsochromic shifts occurs in the spectra of the latter dyes $2 \mathrm{e}(3 \mathrm{e})$ and or $2 \mathrm{f}(3 \mathrm{f})$ in correspondence to the parent dyes 2a (3a).

Comparing the electronic visible absorption spectra of the styryl cyanine dyes (2a-f) with those of the bis styryl cyanine dyes (3a-f) declared that the latter dyes have bathochromically shifted bands related to the former ones, Tables (1) and (2). This can be attributed to the presence of two factors. The first factor is the presence of two electronic charge transfer pathways inside the latter dyes molecules in correspondance to one electronic charge transfer pathways inside the former dyes molecules, Schene (2a). The second factor is increasing conjugation due to increasing the number of methine units $(=\mathrm{CH}-)$ in bis styryl cyanine dyes (3a-f) related to the former styryl cyanine dyes (2a-f) by two methine units (Scheme 1).

Additionally, the visible electronic transitions absorption spectra of the aza-styryl cyanine dyes (bis azastyryl cyanine dyes) $4 a-c$ (5a-c) in $95 \%$ ethanol solution reveals bands in the visible region 440-600 $\mathrm{nm}(450-610$ $\mathrm{nm})$. The positions of these bands and their molar extinction coefficients are largely effected by the type of the phenyl and or the naphthyl ring system in the dyes molecules and by the higher and or lower planarity of the dyes, Table (3).

So, substituting the benzene ring system in dyes $4 \mathrm{a}$ (5a) by naphthyl ring system to give dyes $4 \mathrm{~b}(5 \mathrm{~b})$ and or $4 \mathrm{c}$ (5c) resulted in a noticeable bathochromic shifts for the absorption bands by $10 \mathrm{~nm}$ and or $20 \mathrm{~nm}$ in addition to increasing the intensity of the bands, respectively, Table (3). This can be attributed to increasing $\pi$-delocalization conjugation the latter dyes $4 b(5 b), 4 c(5 c)$ due to the 
Table 4: IR and ${ }^{1} \mathrm{H}$ NMR spectral data of the prepared compounds (2a), (3a), (4a) and (5a)

\begin{tabular}{|c|c|c|}
\hline Compound & IR Spectrum $\left(\mathrm{KBr}, \mathrm{Cm}^{-1}\right)$. & ${ }^{1} \mathrm{H}$ NMR Spectrum (DMSO, $\delta$ ). \\
\hline \multirow{6}{*}{$2 \mathrm{a}$} & 604, 689, 755 (monosubstituted phenyl). & $1.2-1.9\left(\mathrm{~m}, 6 \mathrm{H}, 2 \mathrm{CH}_{3}\right.$ of positions 5,6$)$. \\
\hline & 1155 (C-O-C cyclic). & 2-2.4 (m, $2 \mathrm{H}, \mathrm{CH}_{2}$ of position 6). \\
\hline & $1308,1364(\mathrm{C}-\mathrm{N})$ & 3-3.2 (m, 3H, $\mathrm{CH}_{3}$ of position 4). \\
\hline & $1493(\mathrm{C}=\mathrm{N})$ & 3.3-3.8 (m, $2 \mathrm{H}, \mathrm{CH}_{2}$ of position 4$)$. \\
\hline & $1602(C=C)$. & 4.5-4.7 (m, 2H, 2-CH=). \\
\hline & 2925,2860 (quaternary salt). & $6.7-8.3(\mathrm{~m}, 10 \mathrm{H}$, aromatic). \\
\hline \multirow{6}{*}{ 3a } & 605, 691, 754 (monosubstituted phenyl). & 1.1-1.9 (m, 3H, $\mathrm{CH}_{3}$ of position 6$)$. \\
\hline & 1065, 1157 (C-O-C cyclic). & $2-2.4\left(\mathrm{~m}, 2 \mathrm{H}, \mathrm{CH}_{2}\right.$ of position 6$)$. \\
\hline & $1366,1308(C-N)$ & 3-3.2 (m, $3 \mathrm{H}, \mathrm{CH}_{3}$ of position 4$)$. \\
\hline & $1492(\mathrm{C}=\mathrm{N})$ & 3.3-3.8 $\left(\mathrm{m}, 2 \mathrm{H}, \mathrm{CH}_{2}\right.$ of position 4$)$. \\
\hline & $1598(C=C)$. & $4.6(\mathrm{~m}, 4 \mathrm{H}, 4-\mathrm{CH}=)$. \\
\hline & 2929,2856 (quaternary salt). & $6.6-8.2(\mathrm{~m}, 15 \mathrm{H}$, aromatic). \\
\hline \multirow{8}{*}{$4 a$} & 690, 756 (monosubstituted phenyl). & 1-1.8 $\left(\mathrm{m}, 6 \mathrm{H}, 2 \mathrm{CH}_{3}\right.$ of positions 5,6$)$. \\
\hline & 829, 903 (p.disubstituted phenyl). & $1.9-2.4\left(\mathrm{~m}, 2 \mathrm{H}, \mathrm{CH}_{2}\right.$ of position 6$)$. \\
\hline & 1027, 1122 (C-O-C cyclic). & $2.7-3\left(\mathrm{~m}, 3 \mathrm{H}, \mathrm{CH}_{3}\right.$ of position 4$)$. \\
\hline & $1363(\mathrm{C}-\mathrm{N})$ & 3.2-3.7 (m, $2 \mathrm{H}, \mathrm{CH}_{2}$ of position 4$)$. \\
\hline & $1496,1442(\mathrm{C}=\mathrm{N})$ & 4.5-4.7 (m, 1H, - $\mathrm{CH}=)$. \\
\hline & $1602(C=C)$. & 6.7-8.4 $(\mathrm{m}, 10 \mathrm{H}$, aromatic $+1 \mathrm{OH})$. \\
\hline & 2929 (quaternary salt). & \\
\hline & 3062 (phenolic OH). & \\
\hline \multirow{8}{*}{$5 a$} & 646, 690 (monosubstituted phenyl). & 1-1.9 (m, 3H, $\mathrm{CH}_{3}$ of position 6). \\
\hline & 756, 828 (p.disubstituted phenyl). & $2-2.4\left(\mathrm{~m}, 2 \mathrm{H}, \mathrm{CH}_{2}\right.$ of position 6$)$. \\
\hline & 1023,1130 (C-O-C cyclic). & 2.7-3.1 (m, 3H, $\mathrm{CH}_{3}$ of position 4$)$. \\
\hline & $1362(\mathrm{C}-\mathrm{N})$ & 3.2-3.8 (m, $2 \mathrm{H}, \mathrm{CH}_{2}$ of position 4$)$. \\
\hline & $1496(\mathrm{C}=\mathrm{N})$ & $4.6(\mathrm{~m}, 2 \mathrm{H}, 2-\mathrm{CH}=)$. \\
\hline & $1599(C=C)$. & $6.6-8.5(\mathrm{~m}, 15 \mathrm{H}$, aromatic $+2 \mathrm{OH})$ \\
\hline & 2930 (quaternary salt). & \\
\hline & 3058 (phenolic $\mathrm{OH}$ ). & \\
\hline
\end{tabular}

presence of naphthyl ring systems in correspondence to phenyl ring system in the former dyes $4 \mathrm{a}(5 \mathrm{a})$.

It also, interested to notice that, substituted $\mathrm{X}=$ 2.0H, 5, 6-benz by $\mathrm{X}=2.0 \mathrm{H}, 3$, 4-benz transferring from dyes $4 \mathrm{~b}(5 \mathrm{~b})$ to dyes $4 \mathrm{c}(5 \mathrm{c})$ cause bathochromic shifts for the absorption bands by $10 \mathrm{~nm}$, Table (3). This may be related to the higher structure planarity of the dyes $4 \mathrm{c}(5 \mathrm{c})$ in correspondence to the lower structure planarity of the dyes $4 \mathrm{~b}(5 \mathrm{~b})$. Higher structure planarity dyes make easier, faster and facilitate the electronic charge transfer pathways to the quaternary pyrazolium and or oxazolium salt residue, and consequently, bathochromic shifts occurs. Inversely, lower structure planarity dyes resulted in difficulty and slowing the electronic charge transfer pathways to the quaternary pyrazolium and or oxazolium salt residue, and accordingly hypsochromic shifts occurs.
Comparing the electronic visible absorption spectra of the aza-styryl cyanine dyes (4a-c) with those of the bis azastyryl cyanine dyes $(5 a-c)$ declared that the latter dyes have bathochromically shifted bands related to the former ones, Table (3). This can be attributed to the presence of two factors. The first factor is the presence of two electronic charge transfer pathways inside the latter dyes molecules in correspondance to one electronic charge transfer pathways inside the former dyes molecules, Scheme (2b). The second factor is increasing conjugation due to increasing the number of aza-methine units $(-\mathrm{CH}=\mathrm{N}-)$ in bis aza-styryl cyanine dyes (5a-c) related to the former azastyryl cyanine dyes (4a-c) by one aza-methine unit (Scheme 1).

\section{CONCLUSIONS}

\section{3}


The electronic visible absorption spectra of styryl cyanine dyes (bis styryl cyanine dyes) 2a-f (3a-f) and or the aza-styryl cyanine dyes (bis aza-styryl cyanine dyes) 4a-c (5a-c) in 95\% ethanol solution underwent displacements to give bathochromic and or hypsochromic band shifts in addition to increasing and or decreasing the intensity of the absorption bands depending upon various factors. Presence of either electron releasing and or attracting groups in the dyes molecules in the order of: electron pushing group dyes > electron pulling group dyes (for the styryl and bis styryl cyanine dyes). Presence of phenyl and or naphthyl ring system in the order of: naphthyl dyes > phenyl dyes (for azastyryl, bis aza-styryl cyanine dyes). Planarity of the dyes structures in the order of: higher planarity dyes > lower planarity dyes (for the aza-styryl and bis aza-styryl cyanine dyes). Increasing and or decreasing the number of the electronic charge transfer pathways inside the dyes molecules in the order of: two electronic charge transfer pathways dyes > one electronic charge transfer pathways dyes (for the styryl cyanine dyes, bis styryl cyanine dyes, azastyryl cyanine dyes and bis aza-styryl cyanine dyes). Increasing and or decreasing conjugation due to increasing and or decreasing the number of the methine units inside the dyes structure, in the order of: more methine units dyes > less methine units dyes (for the styryl cyanine dyes, bis styryl cyanine dyes). Increasing and or decreasing conjugation due to increasing and or decreasing the the number of the azamethine units inside the dyes structure, in the order of: more aza-methine units dyes > less aza-methine units dyes (for the aza-styryl cyanine dyes and bis aza-styryl cyanine dyes).

The intensity of the colour of the styryl cyanine dyes (bis styryl cyanine dyes) 2a-f (3a-f) and or the aza-styryl cyanine dyes (bis aza-styryl cyanine dyes) 4a-c (5a-c) can be related to suggested two mesomeric electronic transitions structures (A) and (B) producing a delocalized positive charge over the conjugated chromophoric group system of the dyes, Scheme $(2 \mathrm{a}, \mathrm{b})$.

\section{ACKNOWLEDGEMENTS}

We are thankful to the Chemistry department, Faculty of Science, Aswan University, Aswan, Egypt for supporting this work.

\section{REFERENCES}

Antonious, M. S., 1997. Solvent polarity indicators: flexible styryl pyridinium and quinolinium fluorescence probes for medium free-volume. Spectrochimica Acta Part A: Molecular and Biomolecular Spectroscopy 53(11), 317323.

Deligeorgiev, T., Vasilev, A., Kaloyanova, S., Vaquero, J. J., 2010. Styryl dyes synthesis and applications during the last 15 years. Coloration Technology 126, 55-80.

Ephardt, H., Fromherz, P., 1989. Fluorescence and photoisomerization of an amphiphilic aminostilbazohum dye as controlled by the sensitivity of radiationless deactivation to polarity and viscosity. Journal of Physical Chemistry 93, 7717-7725.

Gromov, S.P., Fedorova, O.A., Ushakov, E.N., Buevich, A.V., Baskin, I. I., Pershina, Y. V., 1992. Total synthesis of the mycotoxin (-)-zearalenone based on macrocyclisation using a cinnamyl radical intermediate. Journal of the Chemical society, Perkin Transations 2, 1323-1328.

Hamer, F.M., 1964. The Cyanine Dyes and Related Compounds (New York: Interscience Publishers) 398.

He, G.S., Bhawalkar, J.D., Zhao, C.F., Prasad, P.N., 1995. Optical limiting effect in a two-photon absorption dye doped solid matrix. Applied Physics Letters 67, 2433-2435.

Hong, S., Yoon, S.S., Kang, C., Suh, M, 2004. Hydrophobic Aminostyryl Quinolinium Dyes as New Fluorescent Stains for Proteins in Sodium Dodecyl Sulfatepolyacrylamide Gel. Bulletin of the Korean Chemical Society 25(3), 345-346.

Huang, Y., Coull, J.M., 2008. Diamine catalyzed hemicyanine dye formation from non fluorescent precursors through DNA programmed chemistry. Journal of the American Chemical Society 130(11), 3238-3239.

Jedrzejewska, B., Kabate, J., Pietrzak, M., Paczkowski, J., 2003. Hemicyanine dyes: synthesis, structure and photophysical properties. Dyes and Pigments 58(1), 47 58.

Jedrzejewska, B., Piatrzak, M., Paczkowski, J.P., 2010. Solvent effects on the spectroscopic properties of styryl quinolinium dyes series. Journal of Fluorescence 20(1), 73-86.

Kabatc, J., Osmidowski, B., Paczkowski, J., 2006. The experimental studies on the determination of the ground and excited state dipole moments of some hemicyanine dyes. Spectrochimica Acta Part A: Molecular and Biomolecular Spectroscopy 63 (3), 524-531.

Kovalska, V.B., Kryvorotenko, D.V., Balanda, A.O., Losytskya, M. Yu., Tokar, V.P., Yarmoluk, S. M., 2005. Fluorescent homodimer styrylcyanines: synthesis and spectralluminescent studies in nucleic acids and protein complexes. Dyes and Pigments 67, 47-54.

Li, Q., Lin, G.-L., Peng, B.-X., Li, Z.-X, 1998. Synthesis, characterization and photographic properties of some new styryl cyanine dyes, Dyes and Pigments 38, 211-218.

Matsuoka, J-YJaung M., Fukunishi, K., 1996. Synthesis and properties of new styryl dyes derived from 2,3-dicyano5-methyl pyrazines. Dyes and Pigments 31, 141-153.

Mees, C.E.K., James, T., 1979. The Theory of the photographic Process, Part 1 (Beijing: Science Press); H. Tao Trans.

Pierre, G., 1984. Photographic Chemistry, Part 4 (Beijing: Chinese Film Press); D. Liu Trans.

Preston, P.N., 1980. in Benzimidazoles and Congeneric Tricyclic Compounds, Part 2 Ed, P N Preston (New York: John Wiley); Chap. 10, 531.

Shim, T., Lee, M.H., Kim, D., Kim, H.S., Yoon, K.B., 2009. Fluorescence Properties of hemicyanine in the nanoporous materials with varying pore sizes. Journal of Physical Chemistry B 113(4), 966-969. 
Shindy, H.A., 2007. Synthesis, Characterization and Visible Spectral Behaviour of some Novel Methine, Styryl, and Aza-styryl Cyanine Dyes. Dyes and Pigments 75(2), 344350.

Shindy, H.A., 2012. Synthesis of different classes of five/five membered heterocyclic cyanine dyes: A Review paper. Mini-Reviews in Organic Chemistry 9 (2), 209-222.

Shindy, H.A., 2014. Synthesis of different classes of six membered heterocyclic cyanine dyes: A review. Revue Roumaine de Chimie 59 (2), 117-123.

Shindy, H.A., 2015. Synthesis of different classes of Benz (Naphth)/five membered heterocyclic cyanine dyes: A review. Revue Roumaine de Chimie 60(1), 5-13.

Shindy, H.A., 2015a. Different methods in the synthesis of mono(bi)-heterocyclic six membered cyanine dyes: A Review, Organic Chemistry: An Indian Journal 11(1), 2636.

Shindy, H.A., 2016. Characterization, mechanisms and applications in the chemistry of cyanine dyes: A review. European Journal of Molecular Biotechnology 14(4), 158170.

Shindy, H.A., 2017. Fundamentals in the chemistry of cyanine dyes: A review. Dyes and Pigments 145, 505-513.

Shindy, H.A., Khalafalla, A.K., Goma, M.M., Eed, A.H., 2017. Synthesis, spectral sensitization, solvatochromic and halochromic evaluation of new monomethine and trimethine cyanine dyes. European Journal of Molecular Biotechnology 5(1), 30-42.

Vasilev, A., Deligeorgiev, T., Gadjev, N., Kaloyanova, S., Vaquero, J.J., Alvarez-Buil, J., Baeza, A.G., 2008. Novel environmentally bengin procedures for the synthesis of styryl dyes. Dyes and Pigments 77, 550-555.

Wade Jr. L.G., 1999. Organic Chemistry 4th ed., Pearson Educ., (Prentice Hall, Upper Saddle River, New Jersey 07458, USA), 500-538.

Wade Jr. L.G., 1999a. Organic Chemistry 4th ed. Pearson Educ., (Prentice Hall, Upper Saddle River, New Jersey 07458, USA), 544-604,

Zhao, C.F., Gvishi, R., Narang, U., Rutand, G., Prasad, P.N., 1996. Structures, spectra and lasing properties of new (aminostyryl) pyridinium laser dyes. Journal of Physical Chemistry 100, 4526-4532.

Visit us at: http://bosaljournals.com/chemint/ Submissions are accepted at: editorci@bosaljournals.com 